\title{
Staging Local Art: Transnational History of Ketoprak Rukun Karya in Outer Island Madura in The Age of Globalization
}

\author{
Joko Sayono ${ }^{1 *}$, Ronal Ridhoi ${ }^{2}$, Lutfiah Ayundasari ${ }^{3}$, Muhammad \\ Wahyu Prahardana ${ }^{4}$ \\ 1,2,3,4, History Department, Faculty of Social Sciences, Universitas Negeri Malang
}

*Corresponding author. Email: joko.sayono.fis@um.ac.id

\begin{abstract}
Traditional performing arts are currently lack on interast in urban region, especially in Semenep City, Madura. However, for a long time, the traditional art like Ketoprak Rukun Karya more famous in outer islands of Madura and even in Java. This paper aims to trace the transnationalization of Ketoprak Rukun Karya in the outer islands of Madura and in parts of Java also. This research uses a historical method that have 4 stages, heuristic (collecting sources), criticism, interpretation (analysis and synthesis), and historiography. By using a transnational point of view and also perusing several offline and online sources, such as archives, newspapers, magazines, photos and videos, this paper find out that: since the last 2 decades, Ketoprak Rukun Karya has shown its existence outside Sumenep City. Urban modernization causes lack attention of millennial generation to this traditional art. Ketoprak Rukun Karya experiencing transnationalization to the outer islands of Madura, and even to Java. This ketoprak has a special mission in each of its performances, that is the cultural education.
\end{abstract}

Keywords: Transnational history, ketoprak, Rukun Karya, cultural education, Madura

\section{INTRODUCTION}

From several traditional arts in Madura, there is one art that still exists and survives to this day, namely ketoprak. Local people know him better as ludruk or loddrok [1]-[3]. However, this art still receives less attention from Indonesian historians. Most of the previous studies discussed the art of ketoprak which put more emphasis on the technical aspects of the performance. Whereas the historical element is an interesting study to be discussed further in order to preserve the memory of the local community regarding its cultural arts that have existed since ancient times.[1], [4], [5]

Sumenep Regency is an area that pays attention to the existence of local arts [6], [7, p. 9]. This is evidenced by several arts such as ketoprak, Dhalang Mask, Ojhung, sea alms, and several other traditional arts that are still maintained today. Even though modernization is moving fast in Madura and its surroundings, traditional arts still have a special place in the daily life of the Sumenep people. The proof is that every year the district government holds regular cultural performances in Sumenep Regency [8]. This activity is carried out so that people can get to know traditional culture and not ignore it.

The rapid development of technology accompanied by the emergence of various entertainment venues in Sumenep caused the ketoprak art to lose interest in urban areas [9]. One of the interesting things why this paper was written is that Ketoprak Rukun Karya has undergone a transnationalization of performances outside the City of Sumenep for the last 2 decades. This is because the interest of the Sumenep urban community has shifted from the traditional to the modern. However, Rukun Karya remains a favorite entertainment for the people of Madura Islands, and even Java. Therefore, the performances are mostly in the enclaves of Madurese migrants, especially East Java [10].

The problem that will be answered from this paper is which areas are the basis for the performance of Ketoprak Rukun Karya and how far does the transnationalization of traditional arts performances affect the existence of local Madurese culture? Through a transnational historical perspective, this paper attempts to describe the experience of a ketoprak group from Sumenep when spreading this indigenous Madurese traditional art trans-nationally, considering that the Indonesian state consists of various ethnic groups. In addition, this paper also aims to understand the reasons behind the transnationalization of the performance.

\section{METHODS}

This paper uses the historical method which has four stages, namely source collection (heuristics), criticism, interpretation (analysis and synthesis), and historiography [11]. The author collects and uses several archival sources from the Ketoprak Rukun Karya group collection. Some of these sources are the personal archives of the director of Rukun Karya, newspapers, magazines, photos, and some supporting literature for research. In addition, the writer also 
conducted interviews with the director of Rukun Karya Encung Hariadi (Mas Jaka Linglung) and several Madurese culturalists. A collection of archives and interviews from several sources above were selected and analyzed to find historical facts about the transnationalization of ketoprak performances in the outer islands of Madura to Java. For supporting material for this paper, The researcher also uses several supporting literatures that have examined the history of traditional Madurese arts, especially in Sumenep. The author uses supporting sources in the form of literature, books and articles, such as: the work of Joko Sayono, et al entitled From Ajhing to Ketoprak: The Historical Journey of Ludruk Art in Sumenep Madura Since the 1940s, Helene Bouvier's work entitled Lebur!: Music and Performing Arts in Madurese Society, and some other supporting literature.

The author conducts an in-depth reading and analysis of the three types of sources, then interprets so that accurate facts are obtained regarding the transnationalization process of the Rukun Karya ketoprak performance. In addition, the author also collects facts about efforts to educate Madurese culture outside the island of Madura itself, considering the large number of Madurese scattered in almost all of Indonesia. Then at the final stage, the collected facts are compiled and narrated into a historiography or historical writing of the transnationalization of ketoprak in the era of globalization.

\section{RESULT AND DISCUSSION}

\subsection{Ketoprak Madura Lack of Enthusiasts?}

The art of Loddrok or Ketoprak Madura has a variety of accessories, stories and uniqueness of each. This uniqueness of each group is certainly different so it has its own characteristics. In the art of Loddrok or Ketoprak Madura, it certainly cannot be separated from the audience. In all kinds of art, of course, the audience is the most important thing [2], [3]. Because with the audience the art can be liked and spread widely, of course this also applies to Ketoprak Madura. With this audience, of course, the Ketoprak Madura art can survive to this day (see figure 1).

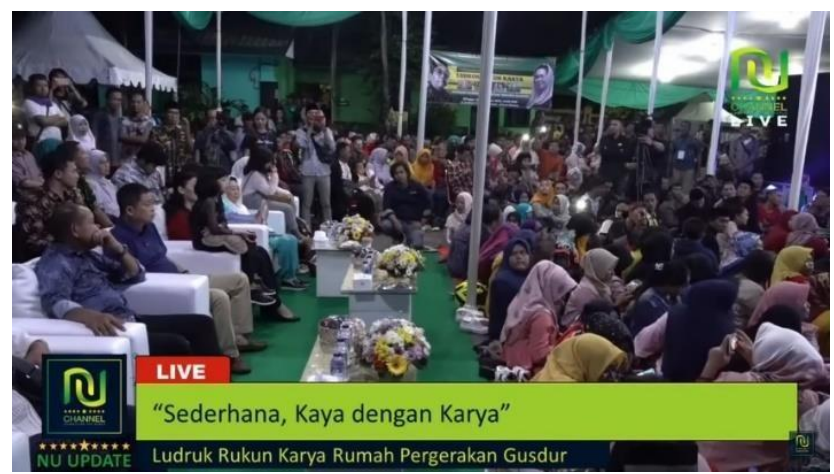

Fig. 1. Viewers of the Rukun Karya ketoprak when performing in Jakarta, 2018

As mentioned earlier that the audience has an important role in Ketoprak Madura. This role can be in the form of faithful watching, holding performances, participating in preserving by playing loddrok and so on. Of course, this role has a reciprocal relationship. This reciprocal relationship occurs between the audience and the perpetrators of Madura ketoprak. Where the performer of ketoprak in performing the show must adjust the likes and desires of the community (audience) in order to be "satisfied and happy" in enjoying the Loddrok Madura show [12], [13].

Things they like and want can be in the form of stories and characterizations. According to Mr. Abdul, in the performance of the ketoprak art in Madura, people will usually follow the preferences of the people in each region [14]. The stories that are displayed are usually about history (Kingdom, region and community leaders), religious (spreading religion), and mythological (fantasy) [15]. Of course in this case will greatly affect the interest of the audience. The more interesting the theme raised, the more Ketoprak audience will be. In addition, the audience also has a favorite too.

In addition to the story that attracts the attention of the audience. There is also a comedy or con-lacon that is performed by Ketoprak players to entertain the public. This is done so that the audience does not get bored when they see Ketoprak and it is displayed verbally and non-verbally caused by speech acts, presuppositions, and conversational implicatures [16]. In this humor, of course, it also pays attention to the environment and the reality of society so that it can be more appropriate (happiness, intimacy, quarrels, divorce and so on). It will cause satisfaction and learning for the audience of Ketoprak Madura [15]. Besides that, it also creates a sense of addiction for the audience to revisit the Madurese ketoprak art performance [17].

These things make the audience interested and follow the course of the ketoprak performance at any time. In addition to the things that trigger the audience, there is also the composition of the audience, from teenagers to the elderly. The thing that makes this Madura ketoprak really unique. One of this uniqueness is the role of teenagers as spectators in the era of technology and modernity. Where teenagers prefer modernity to local arts. But in the art of ketoprak in Madura it is different. Because young people (teenagers) still like the art of Ketoprak. This was expressed by several art figures such as Mr. Abdul that the Ketoprak performance was attended by young people to teenagers. However, there are differences in preferences, such as campussari, which is favored by young people and parents prefer main performances [14]. This is in line with the expression of another humanist, namely Pak Ahmad Darus. He said the same thing as Mr. Rahmad that teenagers still visit Ketoprak and come all the way. Although with various intentions [18].

From the expressions of the two sources, there is a composition of the audience. However, in terms of goals, they each have their own goals. Where these goals can vary such as enjoying the show, meeting friends and so on. Despite the various objectives of this audience composition, it still plays an important role in the Madura ketoprak performance. At least they enlivened the performance. Besides being active in participating in performances staged by Ketoprak Madura. The audience, both young and old, are still actively involved in preserving the art of Madura 
ketoprak. This form of preserving it is in the form of participating in the ketoprak show. It was revealed by Pak Jaka Linglung as the director of the ketoprak harmonious work that many viewers were enthusiastic to participate in the ketoprak art. Even the younger generation wants to be a figure in ketoprak and get a certain pride [19].

This proves that there is an enthusiasm from the audience of this ketoprak who wants to appear in the show. Don't just watch and enjoy the story. There was even a certain pride from the children who participated. Even if it's just a role as a cat or whatever. They are very proud that even their parents support their children in performing in ketoprak. In addition to small children who participated in the ketoprak. There is also the role of people with disabilities who take part and want to be part of the ketoprak art. Where according to $\mathrm{Mr}$. Jaka, this disabled person wants to play ketoprak because he likes jokes and stories. So that it was tried first, it turned out to be a good response from the community. But for now not playing anymore for various reasons [19]. Of course, there are players with disabilities who also play an active role in the performing arts. That this ketoprak art can be played and enjoyed by everyone.

The next factor regarding the loyal audience is the schedule for the ketoprak performance. As it is known at this time that the art of ketoprak is rarely performed due to several factors, one of which is the pandemic. This causes the lack of a performance schedule that is owned by each art. But this is different from the Madurese ketoprak which has a busy schedule of performances starting from Madura to the horseshoe area. This was revealed by Mr. Jaka Linglung that the schedule for the performance of the pillars of work is more than 260 each year [19]. From the statement that was conveyed by Mr. Jaka regarding the loyalty of Madurese ketoprak art lovers. In fact, every year there are almost 200 requests for ketoprak performances in various regions. It is felt as something that is encouraging that art is still being watched by various circles in the era of Modernity.

In each explanation about several factors regarding the interest and enthusiasm of the audience. Starting from the audience's preferences (story and comedy) to participate in preserving the art of ketoprak to the implementation of ketoprak art. This certainly proves that there is a "loyalty" to the Madura ketoprak audience or audience. Where they are willing to travel long distances, stay up late until they are willing to pay expensive fees to hold a Ketoprak show. According to information, the cost of performing Ketoprak ranges from 10-30 million per night. Of course this number is not small for some people. In addition to the cost, there is also the desire of some audience members to participate in the art of ketoprak, such as playing the roles of a cat to the main character. These three things prove that there is a close relationship between the audience's loyalty and the art of Ketoprak.

\subsection{Transnationalization of Ketoprak Rukun Karya}

In ketoprak Madura there are two large groups that are well known, namely the Rukun Karya and the Rukun Famili. Both have their own characteristics of performances, but when viewed from the perspective of enthusiasts and those who enjoy Ketoprak performances, both and other Ketoprak-Ketoprak groups in Madura have one thing in common, namely that the audience comes from rural or island communities. Compared to people who are in the administrative center or urban areas, there are fewer fans of Ketoprak and those who organize Ketoprak as a choice for performing arts in urban community events compared to rural and island communities.

Since the 1950s, the art of ketoprak in Indonesia has begun to develop along with the change in government regimes that tend to be more open to modernization [20]. The art of ketoprak takes a position in one of the theater arts that has undergone many changes in structural and social terms. Ketoprak as an art that grew from the people of East Java has variations in carrying the theme of the story by raising the themes of the storyline such as legends, royal life and small or abangan communities [21]. This art then developed further to several regions by mixing the cultural values of their respective regions, such as the ketoprak or loddrok in Madura.

Ketoprak provides an overview of how the form of art in the form of folk theater performances as a depiction of the expression of community life that developed in his era. One of the ketoprak groups which incidentally is large with a fairly high level of popularity is in the Sumenep Regency area, Saronggi District, namely Rukun Karya. This group was founded in 1977, which is a part of the Ludruk Rukun Famili group, with the characteristics of staging like ludruk which emphasizes performances on comedy performed at the opening and insertions in the storyline. In contrast to the Rukun Famili ludruk, which has a characteristic that is in the memory of an audience, it is an emphasis on storytelling with a comedic character that is not as strong as in Rukun Karya. This assumption is reinforced by connoisseurs and viewers who have seen and compared the two.

From the historical background of Ketoprak, it can be described the reasons why this phenomenon can occur. As before, the historical background of Ketoprak before raising and innovating about the theme of fantasy or imagination as it is now, in the past Ketoprak was a means of performance that was still sacred with the carrying of story themes such as kingdoms originating from chronicles or several legends which before the performance had certain ritual requirements. Must be fulfilled. Judging from this, traditional arts such as loddrok are considered obsolete for urban communities, while for rural and island communities traditional art genres have prestige, and in rural communities there are still many ritual activities that use this loddrok as performing arts [3]. This is evidenced again by how loddrok groups such as Rukun Karya are invited to events such as rokat and sea picking by rural and archipelagic communities because according to the current of modernization, rural communities are thicker in cultural values compared to people who live in urban areas.

In performing the Ketoprak performances, the work has been to various areas in East Java and Jakarta. In East Java, 
the pillars of work often appear in the Madura area and the horseshoe covers the Pasuruan to Banyuwangi areas. In the area of Madura, the harmony of works performs until they reach Kangean Island, Sumenep Regency. Apart from being in East Java, this Ketoprak harmonious work has also appeared in Jakarta at the Haul Gus Dur event in 2018 [19].

Based on the findings of the researchers, Ketoprak Rukun Karya performed local arts in Madurese language, but to areas outside Madura. Of course, these various areas also have Madurese ethnic bases, both native and descendent. What is interesting is the change in the staging area, from the beginning around Sumenep Regency to around the last 20 years it has gone outside the island, even reaching the capital. In addition, this ketoprak also received an offer to perform abroad, namely Singapore. However, due to the Covid-19 pandemic, this ketoprak group failed to leave.

The process of transnationalization is inseparable from the rapid development of technology. Although the information on the performance of Rukun Karya is only done conventionally (notification via community leaders and colleagues at the ketoprak performance), this group is still in great demand by many fans. One thing that makes this group viral is social media, such as YouTube and Facebook. Both of these media indirectly help the promotion of ketoprak until it is known in various areas outside the island of Madura. So the process of transnationalization of Rukun Karya performances in this period of globalization is very dependent on social media. Even in early 2021, this group created its own YouTube Channel which contains short comedy films.

This condition is due to the shift of VCD Player technology to online-based social media. The history of transnationalization of ketoprak performances proves that the influence of progressive media promotions is able to attract the attention of audiences from outside the region. Initially still around Madura, since the early 2000s until now it has expanded to various areas outside the island of Madura. This phenomenon proves that the local Madurese language and culture shows its existence among nations, beyond its existence in the area of origin.

\subsection{A Glorious Mission behind The Jokes}

The name Rukun Karya often sounds familiar to people both inside and outside Madura Island. Through the efforts of each member in maintaining the quality of ketoprak, the quality of each member in various aspects, as well as building interactions with influential figures, has made the name Rukun Karya known and loved by the public. Encung Hariyadi or who is often called as Jaka Linglung is one of the important figures behind the big name of Rukun Karya. He is also one of the successors of the late Haji Suharun, the founding figure of Rukun Karya, in addition Jaka Linglung is a behind-the-scenes figure who has an important role in staging performances as a director.

In running the ketoprak group, Jaka encountered various challenges during his time as a director, one of which was regulating the level of language used by players, such as the use of the language of an advisor to the King who had to use soft language and speak politely. However, as time went on, there was a change, in the past the audience was very concerned about polite behavior and language speaking, in contrast to the audience now who mostly ask for the sangposangan scene, as well as kejhungan (singing) [22].

The use of regional languages has indeed become a characteristic of traditional performing arts performances in various regions. Jaka through Rukun Karya not only provides entertainment to the people, but he also strives to preserve the Madurese language. As a director who is responsible for managing the story line, the stories that are shown in each show consistently use the Madurese language. This is done to educate the public about how to use the Madurese language in society as well as the importance of preserving the Madurese language.

Jaka Linglung often presents historical stories such as the history of Sumenep, the history of the kingdoms in Java, the history of Walisongo, and others. The stories are adapted to the people's preferences. The story should not be monotonous, it must be accompanied by jokes or jokes without compromising historical facts and plots. If the story is presented rigidly, it is possible that the audience will be bored.As a director, Jaka does not forget to convey a moral message, both express and implied in every performance. In relation to the government, Rukun Karya has never publicly criticized it. Rukun Karya only provides an overview through stories about how appropriate a condition goes or a person behaves. Like the story of Kyai who gave advice to the King about how a King should behave.

In addition to displaying historical stories, moral learning and efforts to preserve regional languages. There is also religious learning in the ketoprak story. This was stated by Mr. Jaka Linglung that in every performance religious values were inserted as in Damarwulan's story [19]. He took the example of Damarwulan sabdo palon naya genggong which means the moonlight, the words are very radiating the almighty. Where this is packed with the values of monotheism that are conveyed to the audience.

\section{CONCLUSION}

The rapid development of technology in the era of globalization has not made the traditional art of Ketoprak Rukun Karya lose its identity. It is evident from the many performances every year, with various areas outside mainland Madura. The majority of fans or fans of this ketoprak are in the outer islands of Madura, even in Java. This is due to the longing and love of people outside Madura for the local arts of the area of origin. Therefore, this art performance has been transnationalized to various surrounding areas. Director Ketoprak Rukun Karya took advantage of this opportunity to campaign and popularize the history and local culture of Madura. From this research, it can be concluded that the transnationalization of the Ketoprak Rukun Karya performance is not only a comedy, but there is also a mission of cultural and religious education, especially about language and Islamization in Madura. 


\section{REFERENCES}

[1] J. Sayono, R. Ridhoi, and A. Prasetyawan, DARI AJHING HINGGA KETOPRAK: Perjalanan Historis Kesenian Ludruk di Sumenep Madura Sejak 1940-an. Malang: Java, 2020.

[2] R. Ridhoi, A. N. A. Utama, and J. Sayono, "History of the Ludruk Rukun Famili in Sumenep Madura Island, 1943-1997," 2021.

[3] H. Bouvier, Lèbur: Seni Musik dan Pertunjukan dalam Masyarakat Madura . 2002.

[4] B. Waluyo, D. Said, and F. Kurwidaria, "Ketoprak, Cultural Heritage, and Character Building," 2019, doi: 10.4108/eai.27-4-2019.2286819.

[5] Eka Rizky Yulianti, "KOMODIFIKASI KESENIAN LUDRUK DI ERA REVOLUSI INDUSTRI 4.0 DALAM MENINGKATKAN NILAI EKONOMI PADA LUDRUK RUKUN KARYA DI DESA TANJUNG SARONGGI KABUPATEN SUMENEP," pp. 5-10, 2019.

[6] V. Fajrin and H. Sudarsono, "ANALISIS PERTUMBUHAN EKONOMI DI PULAU MADURA," J. Ekon., 2019, doi: 10.35448/jequ.v9i1.5434.

[7] S. Arifin, "DIGITALISASI PARIWISATA MADURA," J. Komun., 2017, doi: 10.21107/ilkom.v11i1.2835.

[8] J. Sayono, R. Ridhoi, N. Jauhari, I. H. Al Siddiq, A. Prasetyawan, and N. A. D. Restanti, "Those who are forgotten: The existence of Ketoprak Rukun Karya in Sumenep Madura, 1976-2000s," in Community Empowerment through Research, Innovation and Open Access, vol. 1, Routledge, 2021, pp. 103-108.
[9] S. Samidi, "Identitas Budaya Masyarakat Kota: Teater Tradisi di Kota Surabaya Pada Awal Abad XX," Indones. Hist. Stud., 2019, doi: 10.14710/ihis.v3i1.5308.

[10] E. Hariadi, "Wawancara," 2020.

[11] Kuntowijoyo, Metodologi Sejarah. Yogyakarta: Tiara Wacana, 2003.

[12] F. Gilang Aris Pradana, N. Hidayat, Asha, D. Lorry Juniarisca, and A. Imron, "The Potential of 'Ojhung' Tradition Art as Sports Tourism in Sumenep District," 2020, doi: 10.2991/soshec-19.2019.26.

[13] J. Sayono et al., COMMUNITY EMPOWERMENT THROUGH RESEARCH, INNOVATION AND OPEN ACCESS, 1st ed., vol. 1. Routledge, 2021.

[14] "Interview with Mr. Rahmad," 2021.

[15] I. Hasanah and A. Abdillah, "Bentuk Pertunjukan Teater Tradisional Ketoprak Ludruk Rukun Famili Di Desa Tanjung Kecamatan Saronggi Kabupaten Sumenep," J. Pemikir. Seni Pertunjuk., vol. 2, no. 12, pp. 1-13, 2018.

[16] D. Puspita, Nurhayati, and Suhartatik, “Aspek Humor Dalam Ludruk Madura Rukun Karya Episode "Ta' Sak Ngasak" Dalam Perspektif Pragmatik," J. Pendidik. dan Sastra Indones., vol. 1, no. 1, pp. 10-16, 2019.

[17] A. Susanti, Pengambilan Keputusan Yang Dilakukan Masyarakat Dalam Memilih Ludruk Antara Rukun Karya dan Rukun Famili Dilihat Dari Segi Harga dan Daya Tarik. Universitas Wiraraja Sumenep: Fakultas Ekonomi dan Bisnis, 2019.

[18] “Interview with Mr. Ahmad Darus," 2019.

[19] "Interview with Mr. Jaka Linglung," 2021.

[20] Saptomo, "Sejarah Dan Perkembangan Ketoprak Dalam Kehidupan Masyarakat Modern," J. Cakrawala Pendidik., vol. 2, p. 70, 1996, [Online]. Available: https://journal.uny.ac.id/index.php/cp/article/view/92 27.

[21] K. Azali, "Ludruk: Masihkah Ritus Modernisasi?," J. Lakon, vol. 1, no. 1, p. 48, 2012, [Online]. Available: https://ejournal.unair.ac.id/LAKON/article/view/1916.

[22] Avan, "Joko Linglung - Rukun Karya //Arabat Basa Ajaga Tengka," 2021. https://www.youtube.com/watch?v=bu7B87Y3AX0. 